\title{
Dietary Patterns and Pancreatic Cancer Risk: A Meta-Analysis
}

\author{
Pei-Ying Lu ${ }^{1}$, Long Shu ${ }^{2}$, Shan-Shan Shen ${ }^{1}$, Xu-Jiao Chen ${ }^{1, *}$ and Xiao-Yan Zhang ${ }^{2}$ \\ 1 Department of Geriatrics, Zhejiang Hospital, Xihu District, Hangzhou 310013, China; \\ lupy007@sina.com (P.-Y.L.); shenshan305@163.com (S.-S.S.) \\ 2 Department of Nutrition, Zhejiang Hospital, Xihu District, Hangzhou 310013, China; \\ shulong19880920@126.com (L.S.); zxy19740804@sina.com (X.-Y.Z.) \\ * Correspondence: lily197459@163.com; Tel.: +86-571-8159-5100; Fax: +86-571-8798-0175
}

Received: 29 October 2016; Accepted: 23 December 2016; Published: 5 January 2017

\begin{abstract}
A number of studies have examined the associations between dietary patterns and pancreatic cancer risk, but the findings have been inconclusive. Herein, we conducted this meta-analysis to assess the associations between dietary patterns and the risk of pancreatic cancer. MEDLINE (provided by the National Library of Medicine) and EBSCO (Elton B. Stephens Company) databases were searched for relevant articles published up to May 2016 that identified common dietary patterns. Thirty-two studies met the inclusion criteria and were finally included in this meta-analysis. A reduced risk of pancreatic cancer was shown for the highest compared with the lowest categories of healthy patterns (odds ratio, OR $=0.86 ; 95 \%$ confidence interval, CI: $0.77-0.95 ; p=0.004$ ) and light-moderate drinking patterns ( $\mathrm{OR}=0.90 ; 95 \% \mathrm{CI}: 0.83-0.98 ; p=0.02)$. There was evidence of an increased risk for pancreatic cancer in the highest compared with the lowest categories of western-type pattern (OR $=1.24 ; 95 \% \mathrm{CI}: 1.06-1.45 ; p=0.008)$ and heavy drinking pattern $(\mathrm{OR}=1.29$; 95\% CI: $1.10-1.48 ; p=0.002)$. The results of this meta-analysis demonstrate that healthy and light-moderate drinking patterns may decrease the risk of pancreatic cancer, whereas western-type and heavy drinking patterns may increase the risk of pancreatic cancer. Additional prospective studies are needed to confirm these findings.
\end{abstract}

Keywords: dietary patterns; alcohol consumption; pancreatic cancer; meta-analysis

\section{Introduction}

Pancreatic cancer is the fourth leading cause of cancer-related death in both men and women worldwide, with approximately 338,000 new cases occurring each year [1]. In Europe, pancreatic cancer is the fifth most common cause of cancer death in men and the fourth in women [2]. Although the incidence of pancreatic cancer in China is lower than that in the West, it has increased markedly in recent years, becoming a substantial burden in China [3]. It is well-known that pancreatic cancer is a multifactorial disease that results from complex interactions of some etiologic factors, including genetic factors, age, alcohol, cigarette smoking, history of diabetes mellitus and obesity, and dietary factors [4].

Over the past few decades, several epidemiological studies have specifically focused on dietary modification as an important influential factor in the development of pancreatic cancer and examined the link between food groups and individual nutrients and pancreatic cancer risk [5,6]. However, the high inter-correlation between foods and nutrients often makes it difficult to identify the effects of single dietary components [7]. Consequently, dietary pattern analysis has emerged as an approach in assessing the association between whole-diet and diseases, taking into account the combined effects of foods and potentially facilitating nutritional recommendations [8]. 
To date, in medical research there has been considerable attention paid to the relation between dietary patterns and pancreatic cancer risk [9-11]. However, the association of dietary patterns with the risk of pancreatic cancer has been inconclusive. Several studies have also reported the decreased risk of pancreatic cancer associated with nutrients commonly found in fruits and vegetables [12,13]. A study by Larsson et al. [14] has shown no significant association between intake of fruits, vegetables and risk of pancreatic cancer. A recent review by an international panel of experts also concluded that the evidence for an association of vegetable consumption in relation to pancreatic cancer risk is limited and inconsistent [15]. In a large-scale population-based cohort study in Japan, the results showed a decreased risk for pancreatic cancer when comparing the highest versus lowest intakes of coffee [16]. Besides, a population based case-control study conducted in Shanghai, China, showed a statistically significant inverse association with increased tea consumption and pancreatic cancer risk [17]. A previous meta-analysis [18] also reported an overall significant inverse association of low to moderate alcohol consumption (<3 drinks / day) and pancreatic cancer risk, compared with non-drinking. Similarly, a study by Heinen et al. [19] also reported an increased risk of pancreatic cancer for persons with a heavy alcohol intake. In the European Prospective Investigation into Cancer and Nutrition (EPIC), research has reported that the consumption of red and processed meat are not associated with an increased risk of pancreatic cancer, while the consumption of poultry is associated with an increased pancreatic cancer risk [20]. However, to our knowledge, in the update report about pancreatic cancer by World Cancer Research Fund (WCRF) and the American Institute for Cancer Research (AICR), no firm judgment has been made on the relation between red and processed meat and the risk of pancreatic cancer [4]. We therefore conducted a systematic meta-analysis of studies published up to May 2016, to assess the potential associations of dietary patterns with pancreatic cancer risk.

\section{Methods}

\subsection{Literature Search Strategy}

An electronic literature search was performed in MEDLINE (provided by the National Library of Medicine) and EBSCO (Elton B. Stephens Company) to identify relevant studies written in the English and Chinese languages published up to May 2016, with the following keywords or phrases: "dietary pattern" OR "dietary patterns" OR "eating pattern" OR "eating patterns" OR "food pattern" OR "food patterns" OR "diet" OR "alcohol drinking" OR "alcohol consumption" AND "pancreatic cancer" OR "pancreatic neoplasm" OR "pancreatic carcinoma" OR "cancer of pancreatic". Moreover, we searched the references lists of retrieved articles to identify further studies.

\subsection{Studies Included Criteria}

Three independent reviewers read the abstracts of papers retrieved in the initial search to identify studies that examined the relationship between dietary patterns and pancreatic cancer risk. Differences between the three reviewers were resolved by consensus and referred to the four reviewers if necessary. When all reviewers agreed, the full-text versions of articles were reviewed against inclusion and exclusion criteria for the present meta-analysis. To be eligible, the studies had to fulfill the following criteria: (1) The study was an original report investigating the relation between dietary patterns and pancreatic cancer risk; (2) Factor analysis and/or principal component analysis was used to identify food patterns; (3) Odds ratios and percentage of pancreatic cancer (or sufficient information to calculate them) had been listed; (4) If the data in original publication lacked sufficient details, the corresponding author of the study was contacted for additional information by email; (5) Pancreatic cancer diagnoses were confirmed by the clinical manifestations, endoscopic ultrasonography and pathological section.

\subsection{Data Extraction}

The following data were extracted from each publication: the first author's last name, year of publication, country where the study was performed, study design, sample size, number of pancreatic 
cancer, dietary assessment method, identification of dietary patterns and the variables adjusted for in the present analysis.

\subsection{Definition of "High Intake"}

The different forms of alcohol intake were converted into grams of ethanol per day. Alcohol consumption < $12.5 \mathrm{~g} /$ day ( 1 drink/day) for men or $7.5 \mathrm{~g} /$ day ( 0.5 drinks / day) for women was defined as a low alcohol intake; alcohol consumption $>50 \mathrm{~g} /$ day (4 drinks/day) for men or $25 \mathrm{~g} / \mathrm{day}$ ( 2 drinks / day) for women was defined as a high alcohol intake, and alcohol consumption $>12.5 \mathrm{~g} /$ day ( 1 drinks/day) and $<50 \mathrm{~g} /$ day ( 4 drinks/day) for men or $>7.5 \mathrm{~g} /$ day ( 0.5 drinks/day) and $<25 \mathrm{~g} /$ day (2 drinks/day) for women was defined as a light-moderate alcohol intake [21].

\subsection{Assessment of Heterogeneity}

The Cochran's Q statistic and $I^{2}$ statistic were used to evaluate heterogeneity. A $p$ value of Q-test $>0.10$ or $I^{2}<50 \%$ indicated an absence of heterogeneity between studies, and a fixed-effects model (Mantel-Haenszel method) was used to calculated the pooled odds ratios (ORs). If a $p$ value of $Q$-test $\leq 0.10$ or $I^{2} \geq 50 \%$ indicated a high degree of heterogeneity among studies, then a random-effects model (DerSimonnian and Laird method) was used [22].

\subsection{Quality Assessment}

The reviewers independently assessed the risk of bias using the Newcastle-Ottawa Quality Assessment scale for studies included in this meta-analysis [23]. A maximum of nine points was assigned to each study. Only these studies which the majority of the questions were deemed satisfactory (i.e., with a score of 6 or higher) were considered to be of high methodological quality.

\section{Statistical Analysis}

Statistical analyses were performed by using Review Manager, version 5.0 (Nordic Cochrane Centre, Copenhagen, Denmark) and STATA, version 12 (Stata Corp, College Station, Texas City, TX, USA). The original studies reported the results of dietary patterns in terms of tertiles, quartiles, and quintiles of dietary factor scores and pancreatic cancer risk. We conducted this meta-analysis to assess the risk of pancreatic cancer in the highest versus the lowest categories of healthy, western-type, heavy drinking and light-moderate drinking patterns. Multivariable adjusted odds ratios, hazards ratios and relative risks with 95\% confidence intervals (CIs) from individual studies were combined to produce an overall OR. Publication bias was assessed by inspection of the funnel plot and by formal testing for "funnel plot" asymmetry using Begg's test and Egger's test [24]. Sensitivity analysis was conducted to determine whether differences in age, sample size, races and study design affected the conclusions. All statistical tests were two-sided and $P$ values less than 0.05 were considered significant.

\section{Results}

\subsection{Overview of Included Studies for the Systematic Review}

An electronic literature search in the database of MEDLINE and EBSCO identified 695 studies, 663 of which were excluded based on the reasons listed in Figure 1. Thirty-two articles [9-11,14,19,25-51] met the inclusion criteria and were included in this meta-analysis, including 18 [11,14,19,25,26,28,30,32,34-37,39,40,47,49-51] cohort studies and 14 [9,10,27,29,31,33,38,41-46,48] case-control studies. Study characteristics are presented in Table 1. 
Potentially relevant publications identified

from electronic database searches $(n=695)$

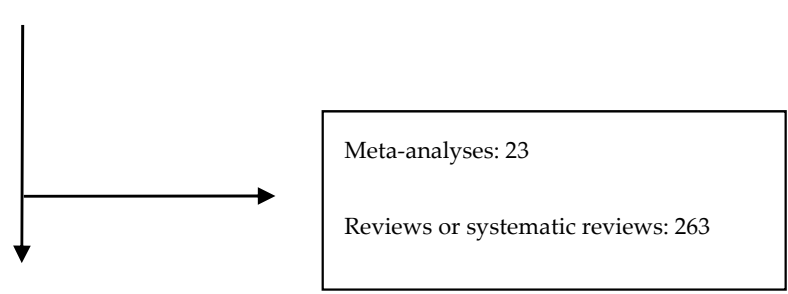

Papers retrieved for more detailed evaluation

$(n=407)$

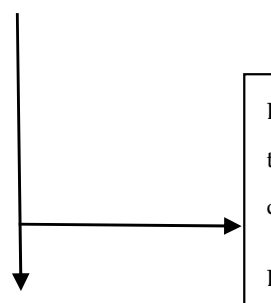

Excluded articles: 357. These were excluded on the basis of title and abstract that clearly did not contain data on dietary patterns or alcohol consumption and pancreatic cancer risk

Eight were focused on single food or nutrients

Studies included in systematic review

$(n=42)$

Two did not provide the data about percentage of

pancreatic cancer or number of each group

Eight reported data using different alcohol

consumption categories.

Studies with outcome data useful for meta-analysis

$(n=32)$

Figure 1. Flow chart of article screening and selection process. 
Table 1. Characteristics of 32 studies included in the meta-analysis (1989-2016).

\begin{tabular}{|c|c|c|c|c|c|c|c|}
\hline $\begin{array}{c}\text { Author } \\
\text { Publication Year }\end{array}$ & Location & Study Design & $\begin{array}{c}\text { Total Number } \\
\text { of Subjects }\end{array}$ & Age & $\begin{array}{l}\text { Diet-Assessment } \\
\text { Method }\end{array}$ & Factors Adjusted for in Analysis & $\begin{array}{l}\text { Dietary Patterns } \\
\text { Identified }\end{array}$ \\
\hline Chan et al. 2013 [9] & United States & Case-control & $\begin{array}{c}532 \text { cases } \\
1701 \text { controls }\end{array}$ & $21-85$ years & FFQ & $\begin{array}{l}\text { Age, race, education, diabetes, body mass index, smoking, alcohol } \\
\text { drinking, physical activity, and total energy. }\end{array}$ & Prudent, western diet \\
\hline Bosetti et al. 2013 [10] & Italy & Case-control & $\begin{array}{c}326 \text { cases } \\
625 \text { controls }\end{array}$ & Mean: 62 years & FFQ & $\begin{array}{l}\text { Age, sex, study center and adjusted for year of interview, } \\
\text { education, body mass index, tobacco smoking, alcohol drinking, } \\
\text { and diabetes. }\end{array}$ & $\begin{array}{l}\text { Animal products, } \\
\text { unsaturated fats, } \\
\text { vitamins and fiber, } \\
\text { starch rich }\end{array}$ \\
\hline $\begin{array}{l}\text { Michaud et al. } \\
2005 \text { [11] }\end{array}$ & United States & Case-control & $\begin{array}{l}\text { 47,493 men } \\
77,179 \text { women }\end{array}$ & $40-75$ years & FFQ & $\begin{array}{l}\text { Age, pack-years of smoking (for current and past smokers in past } \\
15 \text { years), body mass index, physical activity, history of diabetes } \\
\text { mellitus, caloric intake, height, and multivitamin use. }\end{array}$ & Western, prudent \\
\hline $\begin{array}{l}\text { Nöthlings et al. } \\
2008 \text { [25] }\end{array}$ & United States & Cohort & 424,978 & $35-70$ years & FFQ & $\begin{array}{l}\text { Age, sex, and center as strata variables and for diabetes mellitus at } \\
\text { baseline, BMI, energy intake, smoking status ( } 4 \text { categories), and the } \\
\text { number of cigarettes as covariates. }\end{array}$ & Food; simplified food \\
\hline Taunk et al. 2016 [26] & United States & Cohort & 322,848 & 50-71 years & FFQ & $\begin{array}{l}\text { Smoking, BMI, self-reported diabetes (yes, no) and energy-adjusted } \\
\text { saturated fat (continuous). }\end{array}$ & Total meat \\
\hline Chan et al. 2005 [27] & United States & Case-control & $\begin{array}{c}532 \text { cases } \\
1701 \text { controls }\end{array}$ & $21-85$ years & FFQ & Age, sex, and energy intake. & $\begin{array}{l}\text { Total vegetables } \\
\text { and fruits }\end{array}$ \\
\hline $\begin{array}{l}\text { Shigihara et al. } \\
2014[28]\end{array}$ & Japan & Cohort & 32,859 & $40-74$ years & FFQ & $\begin{array}{l}\text { Age in years, body mass index in } \mathrm{kg} / \mathrm{m}^{2} \text {, family history of cancer } \\
\text { (yes or no), history of diabetes mellitus (yes or no), smoking status, } \\
\text { alcohol consumption, time spent walking in hours/day (<0.5, } \\
0.5-0.9 \text {, or } \geq 1 \text { ), education (junior high school or less, high school, } \\
\text { or college/ university or higher), marital status } \\
\text { (married or unmarried), job status (employed or unemployed), } \\
\text { consumption of meat in g/day and total caloric intake in kcal/day. }\end{array}$ & $\begin{array}{l}\text { Total vegetables } \\
\text { and fruits }\end{array}$ \\
\hline Lyon et al. 1993 [29] & United States & Case-control & $\begin{array}{c}149 \text { cases } \\
2363 \text { controls }\end{array}$ & $<65$ years & FFQ & Age, cigarette smoking, and consumption of coffee and alcohol & Red meat \\
\hline $\begin{array}{l}\text { Michaud et al. } \\
2003 \text { [30] }\end{array}$ & United States & Cohort & 88.802 & $30-55$ years & FFQ & $\begin{array}{l}\text { Pack-years of smoking (past } 15 \text { years; current and past smokers } \\
\text { separately), body mass index (quintiles in 1976), history of diabetes } \\
\text { mellitus, caloric intake (quintiles), height (quintiles), physical } \\
\text { activity (continuous), and menopausal status. }\end{array}$ & Total meat intake \\
\hline
\end{tabular}


Table 1. Cont.

\begin{tabular}{|c|c|c|c|c|c|c|c|}
\hline $\begin{array}{c}\text { Author } \\
\text { Publication Year }\end{array}$ & Location & Study Design & $\begin{array}{l}\text { Total Number } \\
\text { of Subjects }\end{array}$ & Age & $\begin{array}{l}\text { Diet-Assessment } \\
\text { Method }\end{array}$ & Factors Adjusted for in Analysis & $\begin{array}{l}\text { Dietary Patterns } \\
\text { Identified }\end{array}$ \\
\hline $\begin{array}{l}\text { Nkondjock et al. } \\
2005 \text { [31] }\end{array}$ & Canada & Case-control & $\begin{array}{c}585 \text { cases } \\
4779 \text { controls }\end{array}$ & $30-74$ years & FFQ & $\begin{array}{l}\text { Age (in } 5 \text {-year groups), smoking }(0,>0-15 \text { and }>15 \text { pack-years), } \\
\text { BMI ( } 5 \text { categories), physical activity (total number of hours } / \text { month } \\
\text { of moderate and strenuous activities), province (eight groups), } \\
\text { educational attainment (years) and total energy intake (as a } \\
\text { continuous variable). }\end{array}$ & $\begin{array}{l}\text { Western, fruit and } \\
\text { vegetables, drinker }\end{array}$ \\
\hline $\begin{array}{l}\text { Vrieling et al. } \\
2009 \text { [32] }\end{array}$ & $\begin{array}{l}\text { European } \\
\text { countries }\end{array}$ & Cohort & 478,400 & $35-70$ years & FFQ & $\begin{array}{l}\text { Age at entry, sex and center and adjusted for energy from fat, } \\
\text { energy from non-fat, weight, height, history of diabetes (yes, no, } \\
\text { missing), and smoking status (never, past (quit <10 year, } 10 \text { year), } \\
\text { current (intensity 1-14,15-24, } 25 \text { cig/day), unknown). }\end{array}$ & $\begin{array}{l}\text { Total fruit and } \\
\text { vegetable } \\
\text { consumption }\end{array}$ \\
\hline $\begin{array}{l}\text { Larsson et al. } \\
2006[14]\end{array}$ & Sweden & Cohort & 81,922 & $>55$ years & FFQ & $\begin{array}{l}\text { Age (in months), sex, education (less than high school, high school } \\
\text { graduate, or more than high school), body mass index ( }<23.0 \text {, } \\
\left.23.0-24.9,25.0-29.9, \text { or } \geq 30 \mathrm{~kg} / \mathrm{m}^{2}\right) \text {, physical activity (hours/week; } \\
\text { four categories), cigarette smoking status and pack-years of } \\
\text { smoking (never, past }<20 \text { pack-years, past } \geq 20 \text { pack-years, } \\
\text { current }<20 \text { pack-years, current } 20-39 \text { pack-years, or current } \\
40 \text { pack-years), history of diabetes (yes or no), multivitamin } \\
\text { supplement use (no use, occasional use, or regular use), and } \\
\text { intakes of total energy (continuous) and alcohol (quartiles). }\end{array}$ & $\begin{array}{l}\text { Fruits and vegetable } \\
\text { consumption }\end{array}$ \\
\hline Jansen et al. 2011 [33] & United States & Case-control & $\begin{array}{l}384 \text { cases } \\
983 \text { controls }\end{array}$ & 24-94 years & FFQ & $\begin{array}{l}\text { Age, sex, smoking, body mass index, energy intake, } \\
\text { and alcohol consumption. }\end{array}$ & $\begin{array}{c}\text { Fruit and vegetable } \\
\text { intake }\end{array}$ \\
\hline $\begin{array}{l}\text { Heinen et al. } \\
2012[34]\end{array}$ & Netherlands & Cohort & 120,852 & $55-69$ years & FFQ & $\begin{array}{l}\text { Age(year), sex, smoking (current smoking: yes/no; number of } \\
\text { cigarettes smoked per day; number of years of smoking), body } \\
\left.\text { mass index }\left(\mathrm{kg} / \mathrm{m}^{2}\right) \text {, family history of pancreatic cancer (yes } / \mathrm{no}\right) \text {, } \\
\text { history of diabetes mellitus (yes } / \text { no), intake of energy (kcal/day), } \\
\text { red meat (g/day), coffee (number of cups/day), } \\
\text { and alcohol (g/day). }\end{array}$ & Fruit and vegetables \\
\hline $\begin{array}{l}\text { Nöthlings et al. } \\
2005 \text { [35] }\end{array}$ & United states & Cohort & 190,545 & $45-75$ years & FFQ & $\begin{array}{l}\text { Sex and time on study and adjusted for age at cohort entry, } \\
\text { ethnicity, history of diabetes mellitus, familial history of pancreatic } \\
\text { cancer, smoking status, and energy intake. }\end{array}$ & Red meat intake \\
\hline $\begin{array}{l}\text { Stolzenberg- } \\
\text { Solomon et al. } \\
2007[36]\end{array}$ & United States & Cohort & 537,302 & $50-71$ years & FFQ & $\begin{array}{l}\text { Age, energy, smoking, BMI, education, race, self- reported } \\
\text { diabetes(yes/no), energy-adjusted saturated fat. }\end{array}$ & Total meat intake \\
\hline
\end{tabular}


Table 1. Cont.

\begin{tabular}{|c|c|c|c|c|c|c|c|}
\hline $\begin{array}{c}\text { Author } \\
\text { Publication Year }\end{array}$ & Location & Study Design & $\begin{array}{c}\text { Total Number } \\
\text { of Subjects }\end{array}$ & Age & $\begin{array}{l}\text { Diet-Assessment } \\
\text { Method }\end{array}$ & Factors Adjusted for in Analysis & $\begin{array}{l}\text { Dietary Patterns } \\
\text { Identified }\end{array}$ \\
\hline $\begin{array}{l}\text { Larsson et al. } \\
2006[37]\end{array}$ & Sweden & Cohort & 61,433 & $>50$ years & FFQ & $\begin{array}{l}\text { Age (in months), education (less than high school, high school } \\
\text { graduate, or more than high school), body mass index }(<23.0, \\
\left.23.0-24.9,25.0-29.9 \text { or } 30 \mathrm{~kg} / \mathrm{m}^{2}\right) \text {, smoking (never smoker, past and } \\
\text { smoked }<20 \text { pack-years, past and smoked } 20 \text { pack-years, current } \\
\text { and smoked }<20 \text { pack-years or current and smoked } 20 \text { pack-years) } \\
\text { and intakes of total energy (continuous), alcohol (quartiles) and } \\
\text { energy-adjusted folate (quartiles). }\end{array}$ & Red meat \\
\hline $\begin{array}{l}\text { Anderson et al. } \\
2002[38]\end{array}$ & United States & Case-control & $\begin{array}{l}193 \text { cases } \\
674 \text { controls }\end{array}$ & 20-64 years & FFQ & $\begin{array}{l}\text { Age, sex, smoking (pack-years and pack-years squared), education, } \\
\text { race, diabetes, white meat, red meat not grilled, and other red meat. }\end{array}$ & Meat intake \\
\hline $\begin{array}{l}\text { Inoue-Choi et al. } \\
\text { 2011 [39] }\end{array}$ & United States & Cohort & 34,642 & $55-69$ years & FFQ & $\begin{array}{l}\text { Age (continuous), race, education (less than high school, high } \\
\text { school, greater than high school), alcohol intake (yes/no),smoking } \\
\text { (current, past, never smoker), physical activity (low, } \\
\text { moderate, high). }\end{array}$ & $\begin{array}{l}\text { Mediterranean; } \\
\text { red meat }\end{array}$ \\
\hline Arem et al. 2013 [40] & United States & Cohort & 537,128 & $50-71$ years & FFQ & $\begin{array}{l}\text { Daily caloric intake, sex (where appropriate), diabetes (yes } / \mathrm{no} \text { ), } \\
\text { body mass index ( } 15 \text { to }<18.5,18.5 \text { to }<25,25 \text { to }<30, \\
30 \text { to } \leq 50 \mathrm{~kg} / \mathrm{m}^{2} \text {, missing) and smoking status (categories } \\
\text { describing never, ever, current, and dose). }\end{array}$ & HEI-2005 \\
\hline Olsen et al. 1989 [41] & United States & Case-control & $\begin{array}{c}212 \text { cases } \\
220 \text { controls }\end{array}$ & $40-84$ years & FFQ & $\begin{array}{l}\text { Age, education level, reported diabetes mellitus history, cigarette } \\
\text { smoking, meat and vegetable consumption. }\end{array}$ & Total alcohol \\
\hline $\begin{array}{l}\text { Silverman et al. } \\
\quad 1995[42]\end{array}$ & United States & Case-control & $\begin{array}{c}486 \text { cases } \\
2109 \text { controls }\end{array}$ & 30-79 years & Questionnaire & $\begin{array}{l}\text { Age, area, cigarette smoking, gallbladder disease, diabetes, } \\
\text { and income. }\end{array}$ & $\begin{array}{l}\text { Total alcohol } \\
\text { consumption }\end{array}$ \\
\hline $\begin{array}{l}\text { Lucenteforte et al. } \\
\quad 2012 \text { [43] }\end{array}$ & $\begin{array}{l}\text { Europe, China, } \\
\text { United States }\end{array}$ & Case-control & $\begin{array}{c}5585 \text { cases } \\
11,827 \text { controls }\end{array}$ & Mean: 64 years & Questionnaire & $\begin{array}{l}\text { Age, sex, race/ethnicity, education, body mass index, history of } \\
\text { diabetes, tobacco smoking (in categories, plus a continuous term), } \\
\text { and center for multicentric studies. }\end{array}$ & $\begin{array}{l}\text { Total alcohol } \\
\text { consumption }\end{array}$ \\
\hline $\begin{array}{l}\text { Heinen et al. } \\
2009[19]\end{array}$ & Netherlands & Cohort & 12,085 & $55-69$ years & FFQ & $\begin{array}{l}\text { Age (years), sex, smoking (smoking status (current smoking: } \\
\text { yes/no); number of cigarettes smoked per day; number of } \\
\text { years of smoking), energy intake (kcal/day), body mass index } \\
\left.\text { (weight }(\mathrm{kg}) / \text { height }(\mathrm{m})^{2}\right) \text {, vegetable intake (g/day), and fruit } \\
\text { intake }(\mathrm{g} / \text { day). }\end{array}$ & Total ethanol intake \\
\hline Tavani et al. 1997 [44] & Italy & Case-control & $\begin{array}{l}361 \text { cases } \\
997 \text { controls }\end{array}$ & $17-79$ years & Questionnaire & $\begin{array}{l}\text { Age, sex, education, smoking status, and history of diabetes, } \\
\text { pancreatitis, and cholelithiasis. }\end{array}$ & Total alcohol intake \\
\hline $\begin{array}{l}\text { Michaud et al. } \\
2010[45]\end{array}$ & $\begin{array}{l}\text { Europe, China, } \\
\text { United States }\end{array}$ & Case-control & $\begin{array}{c}1530 \text { cases } \\
1530 \text { controls }\end{array}$ & $>60$ years & Questionnaire & $\begin{array}{l}\text { Age (continuous), cohort, gender, race (Caucasian, Asian, other), } \\
\text { smoking (dose continuous, duration continuous), diabetes (yes, no, } \\
\text { missing), and BMI (continuous). }\end{array}$ & Total alcohol \\
\hline
\end{tabular}


Table 1. Cont.

\begin{tabular}{|c|c|c|c|c|c|c|c|}
\hline $\begin{array}{c}\text { Author } \\
\text { Publication Year }\end{array}$ & Location & Study Design & $\begin{array}{l}\text { Total Number } \\
\text { of Subjects }\end{array}$ & Age & $\begin{array}{l}\text { Diet-Assessment } \\
\text { Method }\end{array}$ & Factors Adjusted for in Analysis & $\begin{array}{l}\text { Dietary Patterns } \\
\text { Identified }\end{array}$ \\
\hline $\begin{array}{l}\text { Villeneuve et al. } \\
2000[46]\end{array}$ & Canada & Case-control & $\begin{array}{c}583 \text { cases } \\
4813 \text { controls }\end{array}$ & Mean: 59 years & Questionnaire & $\begin{array}{l}\text { Age, province, coffee consumption, cigarette pack-years, energy } \\
\text { intake and dietary fat. }\end{array}$ & Total alcohol \\
\hline Jiao et al. 2009 [47] & United States & Cohort & 470,681 & 50-71 years & Questionnaire & $\begin{array}{l}\text { Sex (for all); smoking variable (never smokers, quit } 10 \text { years ago } \\
\text { and smoked }<20 \text { cigarettes/day, quit } 10 \text { years ago and smoked } 20 \\
\text { cigarettes/day, quit } 5-9 \text { years ago and smoked }<20 \text { cigarettes/day, } \\
\text { quit } 5-9 \text { years ago and smoked } 20 \text { cigarettes/day, quit } 1-4 \text { years } \\
\text { ago and smoked }<20 \text { cigarettes/day, quit } 1-4 \text { years ago and } \\
\text { smoked } 20 \text { cigarettes/day, current smokers with }<20 \\
\text { cigarettes/day, and current smokers with } 20 \text { cigarettes/day); total } \\
\text { energy intake (continuous), energy-adjusted saturated fat, red } \\
\text { meat, and total folate intake (continuous scale); body mass index } \\
\left(<20,20 \text { to }<25,25 \text { to }<30,30 \mathrm{~kg} / \mathrm{m}^{2}, \text { missing); physical activity }\right. \\
\text { (low, moderate, and high level); and history of diabetes. }\end{array}$ & Alcohol use \\
\hline $\begin{array}{l}\text { Rahman et al. } \\
2015 \text { [48] }\end{array}$ & Canada & Case-control & $\begin{array}{c}345 \text { cases } \\
1285 \text { controls }\end{array}$ & $\leq 89$ years & Questionnaire & $\begin{array}{l}\text { Sex, age, body mass index (based on weight one year prior to } \\
\text { questionnaire completion), type } 2 \text { diabetes, pancreatitis, family } \\
\text { history of pancreas cancer, smoking status (non-smoker, } \\
\text { current, former) }\end{array}$ & Alcohol consumption \\
\hline $\begin{array}{l}\text { Gapstur et al. } \\
2011[49]\end{array}$ & United States & cohort & $\begin{array}{c}453,770 \text { men } \\
576,697 \text { women }\end{array}$ & $30-111$ years & Questionnaire & $\begin{array}{l}\text { Age, sex, race/ethnicity, education, marital status, body mass } \\
\text { index, family history of pancreatic cancer, and personal history } \\
\text { of gallstones, diabetes mellitus, or smoking. }\end{array}$ & Alcohol intake \\
\hline $\begin{array}{l}\text { Michaud et al. } \\
2001 \text { [50] }\end{array}$ & United States & cohort & $\begin{array}{c}51,529 \text { men } \\
121,700 \text { women }\end{array}$ & $40-75$ years & FFQ & $\begin{array}{l}\text { Age in 5-year categories, pack-years of smoking (past } 15 \text { years; } \\
\text { current and past smokers separately), BMI (quintiles at baseline), } \\
\text { history of diabetes mellitus, history of cholecysectomy, energy } \\
\text { intake (quintiles), and period. }\end{array}$ & Alcohol intake \\
\hline $\begin{array}{l}\text { Johansen et al. } \\
2009[51]\end{array}$ & Sweden & Cohort & 33,346 & $\begin{array}{l}\text { Mean: } \\
50 \text { for men; } \\
44 \text { for women }\end{array}$ & Questionnaire & $\begin{array}{l}\text { Age, sex, smoking status, Mm-MAST category (Mm-MAST is not } \\
\text { adjusted for -glutamyl transferase (GT) and -GT is not adjusted for } \\
\text { Mm-MAST) and BMI (weight gain not adjusted for BMI). }\end{array}$ & Alcohol consumption \\
\hline
\end{tabular}

FFQ: Food Frequency Questionnaire; HEI-2005: Healthy Eating Index 2005; Mm-MAST: Malmö modification of the brief Michigan Alcoholism Screening Test); BMI: body mass index;

GT: glutamyl transferase. 


\subsection{Healthy Pattern}

The healthy pattern is characterized to have high loadings of foods such as vegetables, fruits, whole grains, olive oil, fish, soy, poultry and low-fat dairy. The relation between healthy pattern and pancreatic cancer risk is shown in Figure 2. There was evidence of a reduced risk of pancreatic cancer in the highest compared with the lowest category of healthy pattern $(\mathrm{OR}=0.85$; 95\% CI: 0.77-0.95; $p=0.004)$, where all studies were combined in the random-effects model. The heterogeneity was apparent in all the studies $\left(p=0.02 ; I^{2}=45 \%\right)$.

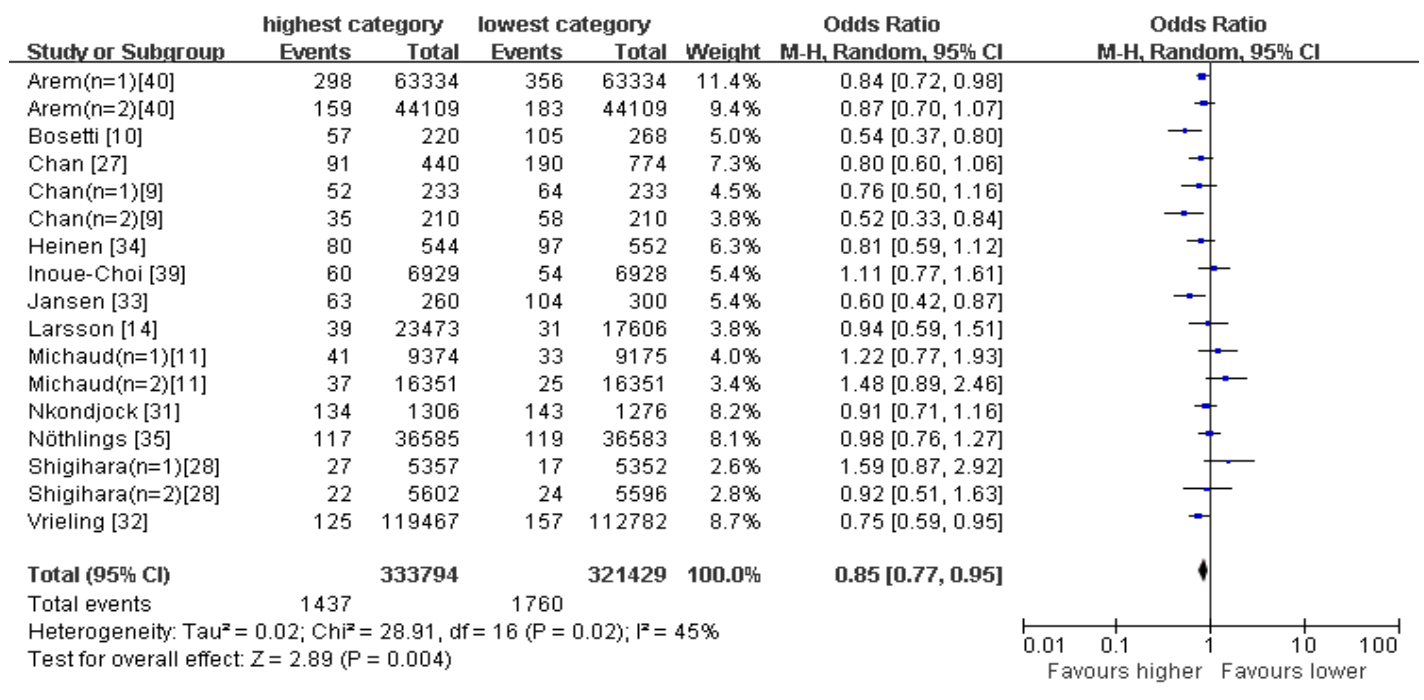

Figure 2. Forest plot for odds ratios (ORs) of the highest compared with the lowest category of intake of the healthy pattern and pancreatic cancer. CI: confidence interval.

\subsection{Western-Type Pattern}

The western-type pattern is characterized to have high consumption of e.g., red and/or processed meat, refined grains, sweets, high-fat dairy products, butter, potatoes and high-fat gravy, and low intakes of fruits and vegetables. Figure 3 shows the forest plot for the risk of pancreatic cancer in the highest compared with the lowest category of western-type pattern. There was significant heterogeneity $\left(I^{2}=70 \%, p<0.00001\right)$ and hence the effect was assessed using the the random-effects model. The results demonstrated that western-type pattern was associated with an increased risk of pancreatic cancer $(\mathrm{OR}=1.24 ; 95 \% \mathrm{CI}: 1.06-1.45 ; p=0.008)$. 


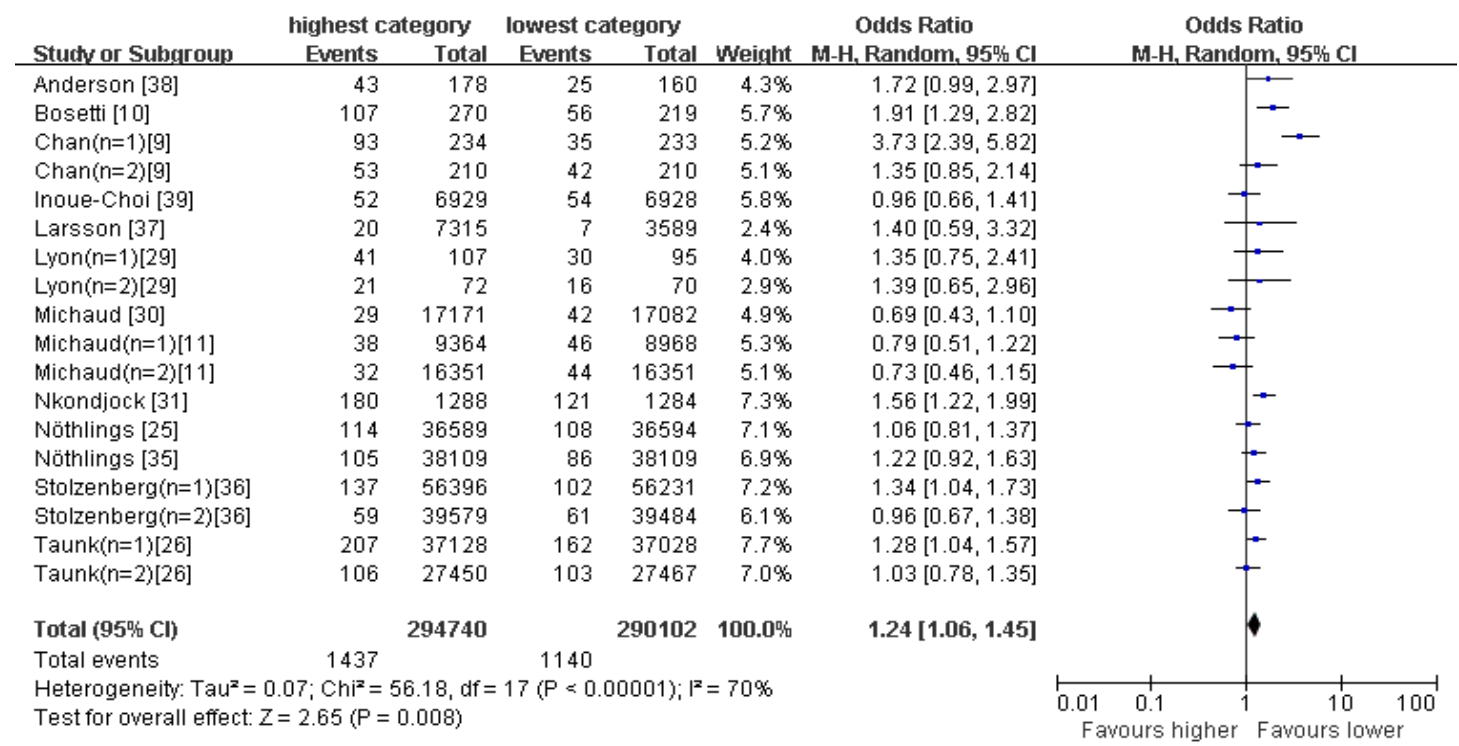

Figure 3. Forest plot for ORs of the highest compared with the lowest category of intake of the western-type pattern and pancreatic cancer.

\subsection{Drinking Pattern}

The drinking pattern is characterized to have high loadings of beers, wines, and white spirits. Eleven articles reporting thirty original studies were identified as, (or to include the) heavy drinking pattern in this meta-analysis (Figure 4). There was evidence of an increased risk of pancreatic cancer in the highest compared with the lowest category of heavy drinking pattern $(\mathrm{OR}=1.28$; 95\% CI: 1.10-1.48; $p=0.002$ ). Data from these studies were assessed using a random-effects model, and there was obvious evidence of heterogeneity $\left(p<0.00001 ; I^{2}=75 \%\right)$. Pooled results from eight articles identified a light-moderate drinking pattern. Figure 5 showed an obvious evidence of a decreased risk of pancreatic cancer in the light-moderate drinking compared with non-drinking $(\mathrm{OR}=0.90$; 95\% CI: 0.83-0.98; $p=0.02$ ). Data from these studies were assessed using random-effects model, and there was obvious evidence of heterogeneity $\left(p=0.0007 ; I^{2}=65 \%\right)$.

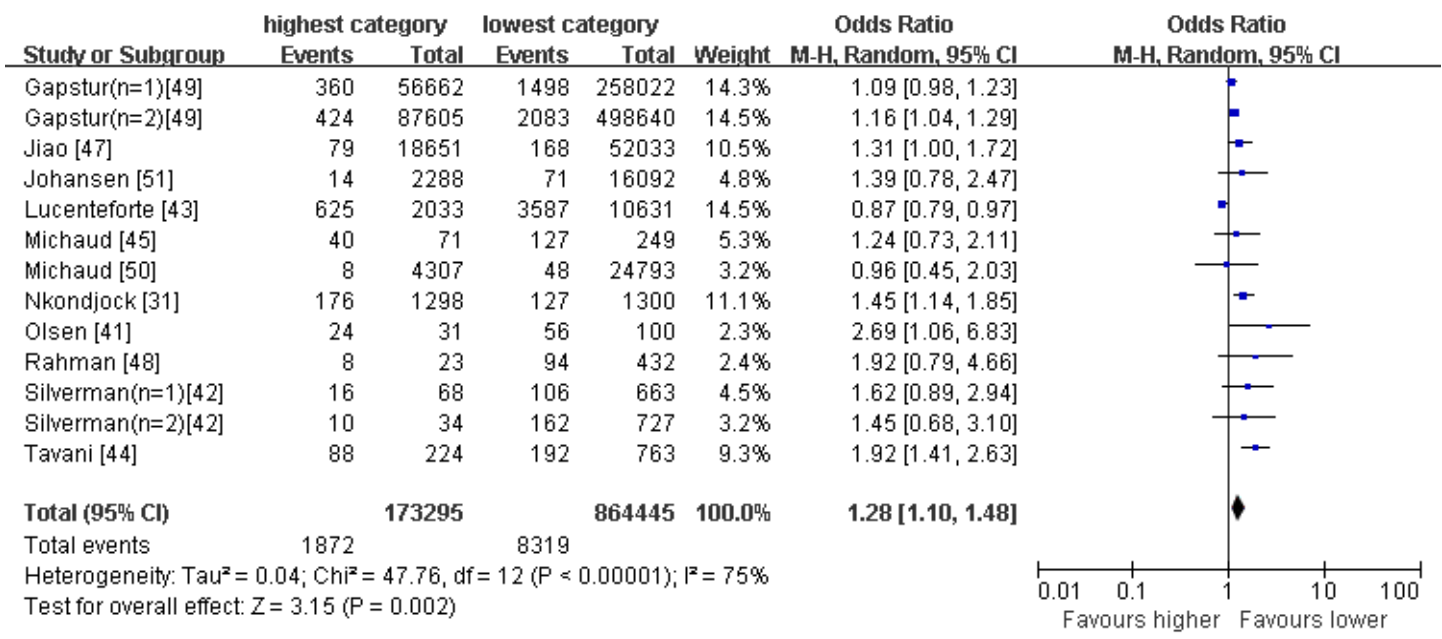

Figure 4. Forest plot for ORs of the highest compared with the lowest category of intake of the heavy drinking pattern and pancreatic cancer. 


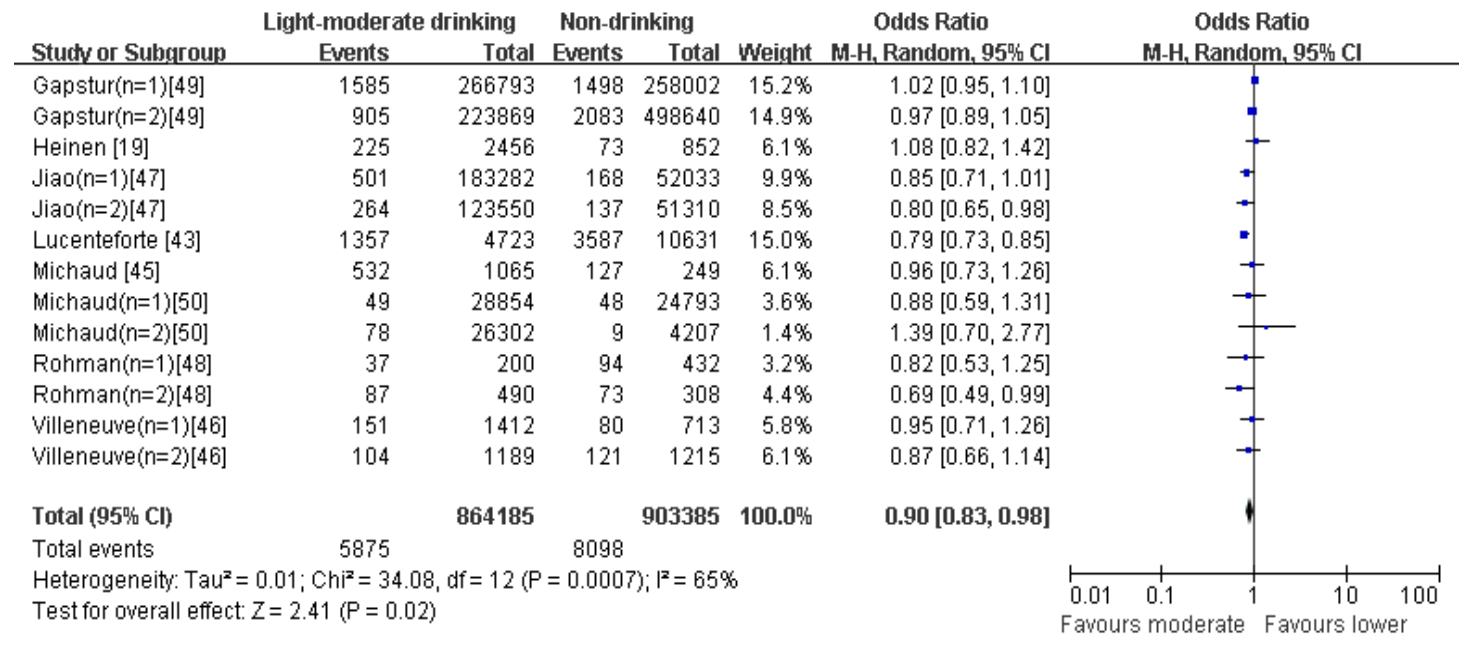

Figure 5. Forest plot for ORs of light-moderate drinking compared with non-drinking intake of the light-moderate drinking pattern and pancreatic cancer.

\subsection{Publication Bias}

Funnel plots revealed little evidence of asymmetry, and thus little evidence of publication bias (highest compared with lowest categories: healthy pattern Begg's test $p=0.275$; Western-type pattern Begg's test $p=0.386$; heavy drinking pattern Begg's test $p=0.218$; and light-moderate drinking pattern Begg's test $p=0.351$ ).

\subsection{Quality Assessment}

The quality of each study in terms of population and sampling methods, description of exposure and outcomes, and statistical adjustment of data, is summarized in Table A1. Of the 32 studies, 26 received a score of 6 or higher on the Newcastle-Ottawa Quality assessment scale and were considered to be of high methodological quality [9-11,14,19,25-28,30-32,34-37,39,40,42,45-51].

\subsection{Sensitivity Analysis}

The sensitivity analysis revealed that differences in age, sample size, race and study design had an impact on the link between dietary patterns and pancreatic cancer risk. When the highest category was compared with the lowest category of healthy pattern, the healthy pattern/pancreatic cancer association was obvious when sample size was less than 5000, study design was case-control and subjects were white and more than 50 years old. When the results were analyzed by removing cohort studies and those with age less than 50 years old, the positive relationship between western-type pattern and pancreatic cancer was more obvious. In addition, the positive association was obvious for those in the highest compared with the lowest category of heavy drinking pattern in studies with a small sample size where the subjects were white and more than 50 years old. Furthermore, the inverse association was obvious for those in the highest compared with the lowest category of light-moderate drinking pattern in studies with a large sample size, case-control design and where the subjects were more than 50 years old. After careful analysis, we found that the factor of pack/years of smoking is difficult to include in this sensitivity analysis. The reason is that the smoking variable is different in the included studies. It is difficult to distinguish the its effect on the relationship between dietary patterns and pancreatic cancer risk. However, we will pay attention to this problem in the following prospective study. In a word, as these variables have a strong effect on the association between different dietary patterns and pancreatic cancer risk, their differences may partially explain the heterogeneity between studies (Table 2). 
Table 2. Dietary patterns and pancreatic cancer: sensitivity analysis.

\begin{tabular}{cccccc}
\hline $\begin{array}{c}\text { Study } \\
\text { Characteristic }\end{array}$ & Category & $\begin{array}{c}\text { Healthy Pattern } \\
\mathbf{( 9 5 \%} \mathbf{C I})\end{array}$ & $\begin{array}{c}\text { Western-Type } \\
\text { Pattern } \mathbf{( 9 5 \%} \mathbf{C I})\end{array}$ & $\begin{array}{c}\text { Heavy Drinking } \\
\text { Pattern } \mathbf{( 9 5 \% ~ C I )}\end{array}$ & $\begin{array}{c}\text { Light-Moderate } \\
\text { Drinking Pattern } \\
\mathbf{9 5 \%} \text { CI) }\end{array}$ \\
\hline \multirow{2}{*}{ Age } & $>50$ & $0.86(0.76,0.98)$ & $1.23(1.02,1.47)$ & $1.23(1.11,1.36)$ & $0.94(0.87,1.00)$ \\
& $<50$ & $0.91(0.71,1.16)$ & $1.28(0.91,1.80)$ & $1.23(0.75,2.02)$ & $0.84(0.69,1.02)$ \\
\hline \multirow{2}{*}{ Sample size } & Large $(>5000)$ & $0.98(0.86,1.11)$ & $1.14(1.00,1.30)$ & $1.14(0.98,1.32)$ & $0.91(0.83,1.00)$ \\
& Small $(<5000)$ & $0.72(0.62,0.85)$ & $1.84(1.22,2.76)$ & $1.73(1.39,2.16)$ & $0.84(0.69,1.02)$ \\
\hline \multirow{2}{*}{ Race } & White & $0.85(0.75,0.95)$ & $1.24(1.06,1.45)$ & $1.33(1.16,1.52)$ & $0.94(0.87,1.00)$ \\
& Yellow and Other & $1.20(0.70,2.06)$ & - & $0.94(0.71,1.25)$ & $0.84(0.69,1.02)$ \\
\hline \multirow{2}{*}{ Study design } & Case-control & $0.70(0.59,0.85)$ & $1.78(1.36,2.32)$ & $1.47(1.06,2.04)$ & $0.81(0.76,0.86)$ \\
& Cohort & $0.95(0.85,1.07)$ & $1.06(0.93,1.20)$ & $1.14(1.06,1.23)$ & $0.96(0.89,1.03)$ \\
\hline
\end{tabular}

\section{Discussion}

To our knowledge, this is the first meta-analysis reporting the associations between different dietary patterns and pancreatic cancer risk. The results indicate that healthy and light-moderate drinking patterns may decrease the risk of pancreatic cancer; whereas western-type and heavy drinking patterns may increase the risk of pancreatic cancer. Data from 32 studies involving 4,803,601 participants were included in our analyses. In the World Cancer Research Fund or American Institute For Cancer Research (WCRF/AICR) report published in 2012, there is limited evidence suggesting that red meat and alcohol intake are risk factors for pancreatic cancer. Our findings add to the existing literature and provide a strong support to the concept that diet is significantly associated with pancreatic cancer risk.

In this meta-analysis, we observed an inverse association between healthy pattern and pancreatic cancer risk. Some previous studies reported the favorable effect of fruit and vegetables intake on the prevention of pancreatic cancer $[37,42,43]$. The protective effect of vegetables and fruits against pancreatic cancer may be plausible due to their high content of antioxidant substances (e.g., vitamin C, vitamin E, carotenoids, phenols, and flavonoids) and dietary fiber. It is acknowledged that vitamin $C$ can protect cells from oxidative DNA damage, thereby blocking carcinogenesis [52]. In addition, antioxidants such as vitamin C/E have an effect on the inflammatory process, particularly chronic inflammatory processes, which may play an important role in pancreatic carcinogenesis [53]. Furthermore, previous studies have also found that high dietary fiber consumption is associated with a decreased risk of pancreatic cancer [54]. Although the exact biologic mechanisms remain unclear, dietary fiber may act as a cancer preventive, for example by lowering the levels of circulating markers of inflammation, which are involved in pancreatic cancer initiation and progression. They also improve insulin metabolism by modulating hormonal pathways linked to pancreatic carcinogenesis $[55,56]$. Finally, vegetables and fruits contain large amounts of folate. A previous meta-analysis has reported that dietary folate plays a protective role in carcinogenesis of pancreatic cancer [57].

The western-type pattern was associated with an increased risk of pancreatic cancer. Our findings were consistent with results from previous studies [9,10], indicating that western and/or animal food pattern can increase the risk of pancreatic cancer. When cooking at high temperatures, red meat may contain heterocyclic amines and polycyclic aromatic hydrocarbons, which are considered carcinogenic [58]. Moreover, high red meat consumption may result in more absorption of haem iron, greater oxidative stress, and potential for DNA damage [59]. Several randomized controlled trails also found that saturated fatty acids were significantly associated with insulin resistance and diabetes, which are risk factors for pancreatic cancer [60]. Furthermore, processed meats are usually preserved with nitrite and may contain $N$-nitroso compounds and heterocyclic amines. Experimental studies found that $N$-nitroso compounds and heterocyclic amines were potent carcinogens that may induce pancreatic cancer [61].

The heavy drinking pattern was associated with an increased risk of pancreatic cancer in our analyses. A published meta-analysis of alcohol consumption and pancreatic cancer risk reported that 
heavy alcohol intake was associated with an increased risk of pancreatic cancer [18]. In fact, alcohol consumption has been consistently recognized as an important carcinogen. As far as we know, there are some plausible explanations for this relationship. Firstly, acetaldehyde, the main metabolite of ethanol, is a known human carcinogen [62]. Secondly, fatty acid esters, products of the interaction between ethanol and fatty acids, accumulate in the pancreas and could induce inflammatory response, fibrosis and thus contribute to pancreatic carcinogenesis [63]. Third, alcohol intake is an important determinant of chronic pancreatitis, a known risk factor for pancreatic cancer [64]. Furthermore, heavy alcohol consumption may also increase production of reactive oxygen species which may result in oxidative DNA damage and dysregulation of proliferation and apoptosis [65]. However, we also observed an inverse association of light-moderate drinking pattern and pancreatic cancer risk. A plausible explanation for a reduced risk of pancreatic cancer with moderate alcohol intake may be that moderate intake lowers the levels of fasting insulin, which is related to the decreased risk of pancreatic cancer $[66,67]$. A recent systematic review and meta-analysis concluded that metabolic syndrome was associated with increased risk of common cancers, including pancreatic cancer [68].

\section{Strengths and Limitations}

This meta-analysis holds its own strengths and limitations. Firstly, this is the first meta-analysis focused on the relation between dietary patterns and pancreatic cancer risk. Besides, we also further explored the associations between heavy and light-moderate drinking patterns and pancreatic cancer risk. Secondly, pancreatic cancer diagnoses were confirmed by the clinical manifestations, endoscopic ultrasonography and pathological section, avoiding misdiagnosis. Thirdly, no signs of publication bias were evident in the funnel plot, and the statistical test for publication bias was non-significant. However, several limitations should be considered in this meta-analysis. Firstly, there was an inconsistent adjustment for potential confounders among the included studies. Consequently, the data included in our analyses might suffer from differing degrees of completeness and accuracy. Secondly, 14 of 32 studies used a case-control design, which is more susceptible to selection and recall bias, especially dietary recall bias, than a cohort design.

\section{Conclusions}

In conclusion, this meta-analysis showed that the healthy and light-moderate drinking patterns are associated with a reduced risk of pancreatic cancer, whereas the western-type and heavy drinking patterns are associated with an increased risk of pancreatic cancer. Our findings confirm the significant associations between dietary patterns and pancreatic cancer risk, and add to the existing literature supporting the concept that diet plays an important role in the prevention of pancreatic cancer. Additional prospective studies are needed to confirm the cause relationship between dietary patterns and pancreatic cancer risk.

Acknowledgments: This study was supported by the Health Department of Zhejiang Province (Grant No. 2017KY174), Science Technology Department of Zhejiang Province (Grant No. 2014C33241), the National Health and Family Planning Commission of Scientific Research Fund of People's Republic of China (Grant No. WKJ2013-2-001), and Innovation disciplines of Zhejiang Province to X.-J.C. The authors thank all participants from Department of Geriatrics and Nutrition, Zhejiang Hospital, Zhejiang, China.

Author Contributions: L.S. and P.-Y.L. conceived and designed the experiments. P.-Y.L., S.-S.S., X.-J.C. and X.-Y.Z. conducted research. P.-Y.L. and L.S. analyzed data and wrote the paper. All authors read and approved the final manuscript.

Conflicts of Interest: The authors declared no conflict of interest. 


\section{Appendix A}

Table A1. Dietary patterns and pancreatic cancer: Assessment of Study Quality.

\begin{tabular}{|c|c|c|c|c|c|c|c|c|c|c|}
\hline \multirow{2}{*}{ Studies } & \multicolumn{4}{|c|}{ Selection } & \multicolumn{2}{|c|}{ Comparability } & \multicolumn{3}{|c|}{ Outcome } & \multirow[t]{2}{*}{ Score } \\
\hline & 1 & 2 & 3 & 4 & $5 \mathrm{~A}$ & $5 B$ & 6 & 7 & 8 & \\
\hline Chan et al. 2013 [9] & * & & * & * & * & & $*$ & * & & $* * * * * *$ \\
\hline Bosetti et al. 2013 [10] & * & & $*$ & * & * & & * & $*$ & * & $* * * * * * *$ \\
\hline Michaud et al. 2005 [11] & * & & * & * & * & & $*$ & $*$ & & $* * * * * *$ \\
\hline Nöthlings et al. 2008 [25] & * & $*$ & $*$ & * & * & & * & $*$ & & $* * * * * * * *$ \\
\hline Taunk et al. 2016 [26] & * & * & * & & * & * & * & $*$ & & $* * * * * * * *$ \\
\hline Chan et al. 2005 [27] & * & & $*$ & * & * & & * & $*$ & * & $* * * * * * *$ \\
\hline Shigihara et al. 2014 [28] & * & $*$ & * & & * & * & $*$ & $*$ & & $* * * * * * * *$ \\
\hline Lyon et al. 1993 [29] & * & & & * & * & & * & $*$ & & $* * * * *$ \\
\hline Michaud et al. 2003 [30] & * & $*$ & * & & * & & $*$ & $*$ & & $* * * * * *$ \\
\hline Nkondjock et al. 2005 [31] & * & & * & * & * & & * & $*$ & & $* * * * * *$ \\
\hline Vrieling et al. 2009 [32] & * & * & * & * & * & & $*$ & $*$ & * & $* * * * * * * *$ \\
\hline Larsson et al. 2006 [14] & * & & * & * & * & & * & * & & $* * * * * * *$ \\
\hline Jansen et al. 2011 [33] & * & & $*$ & & * & & $*$ & $*$ & & $* * * * *$ \\
\hline Heinen et al. 2012 [34] & * & $*$ & * & & * & & $*$ & $*$ & & $* * * * * *$ \\
\hline Nöthlings et al. 2005 [35] & * & $*$ & * & * & * & & $*$ & $*$ & & $* * * * * * *$ \\
\hline Stolzenberg-Solomon et al. 2007 [36] & * & * & * & * & * & & * & * & & $* * * * * * *$ \\
\hline Larsson et al. 2006 [37] & * & * & * & & * & & $*$ & * & * & $* * * * * * *$ \\
\hline Anderson et al. 2002 [38] & * & & & * & * & & * & $*$ & & $* * * * * *$ \\
\hline Inoue-Choi et al. 2011 [39] & * & $*$ & * & * & * & & * & $*$ & * & $* * * * * * * *$ \\
\hline Arem et al. 2013 [40] & * & * & * & & * & * & * & * & & $* * * * * * * *$ \\
\hline Olsen et al. 1989 [41] & * & & & * & * & & $*$ & * & & $* * * * *$ \\
\hline Silverman et al. 1995 [42] & * & & * & * & * & & * & $*$ & & $* * * * * *$ \\
\hline Lucenteforte et al. 2012 [43] & * & & & * & * & & $*$ & $*$ & & $* * * * * *$ \\
\hline Heinen et al. 2009 [19] & $*$ & $*$ & * & & * & * & * & * & & $* * * * * * * *$ \\
\hline Tavani et al. 1997 [44] & * & & & * & * & & * & & & $* * * * * *$ \\
\hline Michaud et al. 2010 [45] & * & & * & * & * & & * & $*$ & & $* * * * * *$ \\
\hline Villeneuve et al. 2000 [46] & * & & * & * & * & & $*$ & $*$ & & $* * * * * *$ \\
\hline Jiao et al. 2009 [47] & $*$ & $*$ & $*$ & & * & & * & $*$ & $*$ & $* * * * * * * *$ \\
\hline Rahman et al. 2015 [48] & $*$ & & * & * & * & & * & $*$ & * & $* * * * * * * *$ \\
\hline Gapstur et al. 2011 [49] & * & * & * & & * & & $*$ & * & & $* * * * * *$ \\
\hline Michaud et al. 2001 [50] & $*$ & * & * & & * & & $*$ & $*$ & & $* * * * * * *$ \\
\hline Johansen et al. 2009 [51] & $*$ & $*$ & $*$ & & * & & $*$ & $*$ & & $* * * * * *$ \\
\hline
\end{tabular}

* For case-control studies, 1 indicates cases independently validated; 2 cases are representative of population; 3 community controls; 4 controls have no history of blood pressure disease; $5 \mathrm{~A}$ study controls for age; $5 \mathrm{~B}$ study controls for additional factor(s); 6 ascertainment of exposure by blinded interview or record; 7 same method of ascertainment used for cases and controls; and 8 non response rate the same for cases and controls. For cohort studies, 1 indicates exposed cohort truly representative; 2 non exposed cohort drawn from the same community; 3 ascertainment of exposure; 4 outcome of interest not present at start; $5 \mathrm{~A}$ cohorts comparable on basis of age; $5 \mathrm{~B}$ cohorts comparable on other factor(s); 6 quality of outcome assessment; 7 follow-up long enough for outcomes to occur; and 8 complete accounting for cohorts.

\section{References}

1. Ferlay, J.; Soerjomataram, I.; Ervik, M.; Forman, D.; Bray, F.; Dikshit, R.; Eser, S.; Mathers, C.; Rebelo, M.; Parkin, D.M. GLOBOCAN 2012 v10, Cancer Incidence and Mortality Worldwide: IARC Cancer Base No. 11; International Agency for Research on Cancer: Lyon, France, 2013.

2. La Vecchia, C.; Bosetti, C.; Lucchini, F.; Bertuccio, P.; Negri, E.; Boyle, P.; Levi, F. Cancer mortality in Europe, 2000-2004, and an overview of trends since 1975. Ann. Oncol. 2010, 21, 1323-1360. [CrossRef] [PubMed]

3. Chen, W.; Zheng, R.; Zeng, H.; Zhang, S. The updated incidences and mortalities of major cancers in China, 2011. Chin. J. Cancer 2015, 34, 502-507. [CrossRef] [PubMed]

4. World Cancer Research Fund; American Institute for Cancer Research. Continuous Update Report. Food, Nutrition, Physical Activity, and the Prevention of Pancreatic Cancer; AICR: Washington, DC, USA, 2012. 
5. Silverman, D.T.; Swanson, C.A.; Gridley, G.; Wacholder, S.; Greenberg, R.S.; Brown, L.M.; Hayes, R.B.; Swanson, G.M.; Schoenberg, J.B. Dietary and nutritional factors and pancreatic cancer: A case-control study based on direct interviews. J. Natl. Cancer Inst. 1998, 90, 1710-1719. [CrossRef] [PubMed]

6. Ji, B.T.; Chow, W.H.; Gridley, G.; McLaughlin, J.K.; Dai, Q.; Wacholder, S.; Hatch, M.C.; Gao, Y.T.; Fraumeni, J.F., Jr. Dietary factors and the risk of pancreatic cancer: A case-control study in Shanghai, China. Cancer Epidemiol. Biomark. Prev. 1995, 4, 885-893.

7. Zhang, X.Y.; Shu, L.; Si, C.J.; Yu, X.L.; Liao, D.; Gao, W.; Zhang, L.; Zheng, P.F. Dietary patterns, alcohol consumption and risk of coronary heart disease in adults: A Meta-Analysis. Nutrients 2015, 7, 6582-6605. [CrossRef] [PubMed]

8. Hu, F.B. Dietary pattern analysis: A new direction in nutritional epidemiology. Curr. Opin. Lipidol. 2002, 13, 3-9. [CrossRef] [PubMed]

9. Chan, J.M.; Gong, Z.; Holly, E.A.; Bracci, P.M. Dietary patterns and risk of pancreatic cancer in a large population-based case-control study in the San Francisco Bay Area. Nutr. Cancer 2013, 65, 157-164. [CrossRef] [PubMed]

10. Bosetti, C.; Bravi, F.; Turati, F.; Edefonti, V.; Polesel, J.; Decarli, A.; Negri, E.; Talamini, R.; Franceschi, S.; La Vecchia, C. Nutrient-based dietary patterns and pancreatic cancer risk. Ann. Epidemiol. 2013, 23, 124-128. [CrossRef] [PubMed]

11. Michaud, D.S.; Skinner, H.G.; Wu, K.; Hu, F.; Giovannucci, E.; Willett, W.C.; Colditz, G.A.; Fuchs, C.S. Dietary patterns and pancreatic cancer risk in men and women. J. Natl. Cancer Inst. 2005, 97, 518-524. [CrossRef] [PubMed]

12. Jansen, R.J.; Robinson, D.P.; Stolzenberg-Solomon, R.Z.; Bamlet, W.R.; de Andrade, M.; Oberg, A.L.; Rabe, K.G.; Anderson, K.E. Nutrients from fruit and vegetable consumption reduce the risk of pancreatic cancer. J. Gastrointest. Cancer 2013, 44, 152-161. [CrossRef] [PubMed]

13. Olsen, G.W.; Mandel, J.S.; Gibson, R.W.; Wattenberg, L.W.; Schuman, L.M. Nutrients and pancreatic cancer: A population-based case-control study. Cancer Causes Control 1991, 2, 291-297. [CrossRef] [PubMed]

14. Larsson, S.C.; Håkansson, N.; Näslund, I.; Bergkvist, L.; Wolk, A. Fruit and vegetable consumption in relation to pancreatic cancer risk: A prospective study. Cancer Epidemiol. Biomark. Prev. 2006, 15, 301-305. [CrossRef] [PubMed]

15. World Cancer Research Fund; American Institute for Cancer Research. Food, Nutrition, Physical Activity, and the Prevention of Cancer: A Global Perspective; AICR: Washington, DC, USA, 2007.

16. Luo, J.; Inoue, M.; Iwasaki, M.; Sasazuki, S.; Otani, T.; Ye, W.; Tsugane, S.; JPHC Study Group. Green tea and coffee intake and risk of pancreatic cancer in a large-scale, population-based cohort study in Japan (JPHC study). Eur. J. Cancer Prev. 2007, 16, 542-548. [CrossRef] [PubMed]

17. Wang, J.; Zhang, W.; Sun, L.; Yu, H.; Ni, Q.X.; Risch, H.A.; Gao, Y.T. Green tea drinking and risk of pancreatic cancer: A large-scale, population-based case-control study in urban Shanghai. Cancer Epidemiol. 2012, 36, 354-358. [CrossRef]

18. Tramacere, I.; Scotti, L.; Jenab, M.; Bagnardi, V.; Bellocco, R.; Rota, M.; Corrao, G.; Bravi, F.; Boffetta, P.; La Vecchia, C. Alcohol drinking and pancreatic cancer risk: A meta-analysis of the dose-risk relation. Int. J. Cancer 2010, 126, 1474-1486. [CrossRef] [PubMed]

19. Heinen, M.M.; Verhage, B.A.; Ambergen, T.A.; Goldbohm, R.A.; van den Brandt, P.A. Alcohol consumption and risk of pancreatic cancer in the Netherlands cohort study. Am. J. Epidemiol. 2009, 169, 1233-1242. [CrossRef] [PubMed]

20. Rohrmann, S.; Linseisen, J.; Nöthlings, U.; Overvad, K.; Egeberg, R.; Tjønneland, A.; Boutron-Ruault, M.C.; Clavel-Chapelon, F.; Cottet, V.; Pala, V.; et al. Meat and fish consumption and risk of pancreatic cancer: Results from the European Prospective Investigation into Cancer and Nutrition. Int. J. Cancer 2013, 132, 617-624. [CrossRef] [PubMed]

21. U.S. Government. Alcoholic Beverages: Dietary Guidelines for Americans 2005; U.S. Government Printing Office: Washington, DC, USA, 2005.

22. Higgins, J.P.; Thompson, S.G.; Deeks, J.J.; Altman, D.G. Measuring inconsistency in meta-analyses. BMJ 2003, 327, 557-560. [CrossRef] [PubMed]

23. Stang, A. Critical evaluation of the Newcastle-Ottawa scale for the assessment of the quality of nonrandomized studies in meta-analyses. Eur. J. Epidemiol. 2010, 25, 603-660. [CrossRef] [PubMed] 
24. Begg, C.B.; Mazumdar, M. Operating characteristics of a rank correlation test for publication bias. Biometrics 1994, 50, 1088-1101. [CrossRef] [PubMed]

25. Nöthlings, U.; Murphy, S.P.; Wilkens, L.R.; Boeing, H.; Schulze, M.B.; Bueno-de-Mesquita, H.B.; Michaud, D.S.; Roddam, A.; Rohrmann, S.; Tjønneland, A.; et al. A food pattern that is predictive of flavonol intake and risk of pancreatic cancer. Am. J. Clin. Nutr. 2008, 88, 1653-1662. [CrossRef] [PubMed]

26. Taunk, P.; Hecht, E.; Stolzenberg-Solomon, R. Are meat and heme iron intake associated with pancreatic cancer? Results from the NIH-AARP diet and health cohort. Int. J. Cancer 2016, 138, 2172-2189. [CrossRef] [PubMed]

27. Chan, J.M.; Wang, F.; Holly, E.A. Vegetable and fruit intake and pancreatic cancer in a population- based case-control study in the San Francisco bay area. Cancer Epidemiol. Biomark. Prev. 2005, 14, 2093-2097. [CrossRef] [PubMed]

28. Shigihara, M.; Obara, T.; Nagai, M.; Sugawara, Y.; Watanabe, T.; Kakizaki, M.; Nishino, Y.; Kuriyama, S.; Tsuji, I. Consumption of fruits, vegetables, and seaweeds (sea vegetables) and pancreatic cancer risk: The Ohsaki Cohort Study. Cancer Epidemiol. 2014, 38, 129-136. [CrossRef] [PubMed]

29. Lyon, J.L.; Slattery, M.L.; Mahoney, A.W.; Robison, L.M. Dietary intake as a risk factor for cancer of the exocrine pancreas. Cancer Epidemiol. Biomark. Prev. 1993, 2, 513-518.

30. Michaud, D.S.; Giovannucci, E.; Willett, W.C.; Colditz, G.A.; Fuchs, C.S. Dietary meat, dairy products, fat, and cholesterol and pancreatic cancer risk in a prospective study. Am. J. Epidemiol. 2003, 157, 1115-1125. [CrossRef] [PubMed]

31. Nkondjock, A.; Krewski, D.; Johnson, K.C.; Ghadirian, P.; Canadian Cancer Registries Epidemiology Research Group. Dietary patterns and risk of pancreatic cancer. Int. J. Cancer 2005, 114, 817-823. [CrossRef] [PubMed]

32. Vrieling, A.; Verhage, B.A.; van Duijnhoven, F.J.; Jenab, M.; Overvad, K.; Tjønneland, A.; Olsen, A.; Clavel-Chapelon, F.; Boutron-Ruault, M.C.; Kaaks, R.; et al. Fruit and vegetable consumption and pancreatic cancer risk in the European Prospective Investigation into Cancer and Nutrition. Int. J. Cancer 2009, 124, 1926-1934. [CrossRef] [PubMed]

33. Jansen, R.J.; Robinson, D.P.; Stolzenberg-Solomon, R.Z.; Bamlet, W.R.; de Andrade, M.; Oberg, A.L.; Hammer, T.J.; Rabe, K.G. Fruit and vegetable consumption is inversely associated with having pancreatic cancer. Cancer Causes Control 2011, 22, 1613-1625. [CrossRef] [PubMed]

34. Heinen, M.M.; Verhage, B.A.; Goldbohm, R.A.; van den Brandt, P.A. Intake of vegetables, fruits, carotenoids and vitamins $C$ and $E$ and pancreatic cancer risk in The Netherlands Cohort Study. Int. J. Cancer 2012, 130, 147-158. [CrossRef] [PubMed]

35. Nöthlings, U.; Wilkens, L.R.; Murphy, S.P.; Hankin, J.H.; Henderson, B.E.; Kolonel, L.N. Meat and fat intake as risk factors for pancreatic cancer: The multiethnic cohort study. J. Natl. Cancer Inst. 2005, 97, 1458-1465. [CrossRef] [PubMed]

36. Stolzenberg-Solomon, R.Z.; Cross, A.J.; Silverman, D.T.; Schairer, C.; Thompson, F.E.; Kipnis, V.; Subar, A.F.; Hollenbeck, A.; Schatzkin, A.; Sinha, R. Meat and meat-mutagen intake and pancreatic cancer risk in the NIH-AARP cohort. Cancer Epidemiol. Biomark. Prev. 2007, 16, 2664-2675. [CrossRef] [PubMed]

37. Larsson, S.C.; Håkanson, N.; Permert, J.; Wolk, A. Meat, fish, poultry and egg consumption in relation to risk of pancreatic cancer: A prospective study. Int. J. Cancer 2006, 118, 2866-2870. [CrossRef] [PubMed]

38. Anderson, K.E.; Sinha, R.; Kulldorff, M.; Gross, M.; Lang, N.P.; Barber, C.; Harnack, L.; DiMagno, E.; Bliss, R.; Kadlubar, F.F. Meat intake and cooking techniques: Associations with pancreatic cancer. Mutat. Res. 2002, 506-507, 225-231. [CrossRef]

39. Inoue-Choi, M.; Flood, A.; Robien, K.; Anderson, K. Nutrients, food groups, dietary patterns, and risk of pancreatic cancer in postmenopausal women. Cancer Epidemiol. Biomark. Prev. 2011, 20, 711-714. [CrossRef] [PubMed]

40. Arem, H.; Reedy, J.; Sampson, J.; Jiao, L.; Hollenbeck, A.R.; Risch, H.; Mayne, S.T.; Stolzenberg-Solomon, R.Z. The Healthy Eating Index 2005 and risk for pancreatic cancer in the NIH-AARP study. J. Natl. Cancer Inst. 2013, 105, 1298-1305. [CrossRef]

41. Olsen, G.W.; Mandel, J.S.; Gibson, R.W.; Wattenberg, L.W.; Schuman, L.M. A case-control study of pancreatic cancer and cigarettes, alcohol, coffee and diet. Am. J. Public Health 1989, 79, 1016-1019. [CrossRef] [PubMed]

42. Silverman, D.T.; Brown, L.M.; Hoover, R.N.; Schiffman, M.; Lillemoe, K.D.; Schoenberg, J.B.; Swanson, G.M.; Hayes, R.B.; Greenberg, R.S. Alcohol and pancreatic cancer in blacks and whites in the United States. Cancer Res. 1995, 55, 4899-4905. [PubMed] 
43. Lucenteforte, E.; La Vecchia, C.; Silverman, D.; Petersen, G.M.; Bracci, P.M.; Ji, B.T.; Bosetti, C.; Li, D.; Gallinger, S. Alcohol consumption and pancreatic cancer: A pooled analysis in the International Pancreatic Cancer Case-Control Consortium (PanC4). Ann. Oncol. 2012, 23, 374-382. [CrossRef] [PubMed]

44. Tavani, A.; Pregnolato, A.; Negri, E.; La Vecchia, C. Alcohol consumption and risk of pancreatic cancer. Nutr. Cancer 1997, 27, 157-161. [CrossRef] [PubMed]

45. Michaud, D.S.; Vrieling, A.; Jiao, L.; Mendelsohn, J.B.; Steplowski, E.; Lynch, S.M.; Wactawski-Wende, J.; Arslan, A.A.; Bas Bueno-de-Mesquita, H.; Fuchs, C.S.; et al. Alcohol intake and pancreatic cancer: A pooled analysis from the pancreatic cancer cohort consortium (PanScan). Cancer Causes Control 2010, 21, 1213-1225. [CrossRef] [PubMed]

46. Villeneuve, P.J.; Johnson, K.C.; Hanley, A.J.; Mao, Y. Alcohol, tobacco and coffee consumption and the risk of pancreatic cancer: Results from the Canadian Enhanced Surveillance System case-control project. Canadian Cancer Registries Epidemiology Research Group. Eur. J. Cancer Prev. 2000, 9, 49-58. [CrossRef] [PubMed]

47. Jiao, L.; Silverman, D.T.; Schairer, C.; Thiébaut, A.C.; Hollenbeck, A.R.; Leitzmann, M.F.; Schatzkin, A.; Stolzenberg-Solomon, R.Z. Alcohol use and risk of pancreatic cancer: The NIH-AARP Diet and Health Study. Am. J. Epidemiol. 2009, 169, 1043-1051. [CrossRef] [PubMed]

48. Rahman, F.; Cotterchio, M.; Cleary, S.P.; Gallinger, S. Association between alcohol consumption and pancreatic cancer risk: A case-control study. PLoS ONE 2015, 10, e0124489. [CrossRef] [PubMed]

49. Gapstur, S.M.; Jacobs, E.J.; Deka, A.; McCullough, M.L.; Patel, A.V.; Thun, M.J. Association of alcohol intake with pancreatic cancer mortality in never smokers. Arch. Intern. Med. 2011, 171, 444-451. [CrossRef] [PubMed]

50. Michaud, D.S.; Giovannucci, E.; Willett, W.C.; Colditz, G.A.; Fuchs, C.S. Coffee and alcohol consumption and the risk of pancreatic cancer in two prospective United States cohorts. Cancer Epidemiol. Biomark. Prev. 2001, 10, 429-437.

51. Johansen, D.; Borgström, A.; Lindkvist, B.; Manjer, J. Different markers of alcohol consumption, smoking and body mass index in relation to risk of pancreatic cancer. A prospective cohort study within the Malmö Preventive Project. Pancreatology 2009, 9, 677-686. [CrossRef] [PubMed]

52. Pathak, S.K.; Sharma, R.A.; Steward, W.P.; Mellon, J.K.; Griffiths, T.R.; Gescher, A.J. Oxidative stress and cyclooxygenase activity in prostate carcinogenesis: Targets for chemopreventive strategies. Eur. J. Cancer 2005, 41, 61-70. [CrossRef] [PubMed]

53. Algül, H.; Treiber, M.; Lesina, M.; Schmid, R.M. Mechanisms of disease: Chronic inflammation and cancer in the pancreas-A potential role for pancreatic stellate cells? Nat. Clin. Pract. Gastroenterol. Hepatol. 2007, 4, 454-462. [CrossRef] [PubMed]

54. Wang, C.H.; Qiao, C.; Wang, R.C.; Zhou, W.P. Dietary fiber intake and pancreatic cancer risk: A meta-analysis of epidemiologic studies. Sci. Rep. 2015, 5, 10834. [CrossRef] [PubMed]

55. Gukovsky, I.; Li, N.; Todoric, J.; Gukovskaya, A.; Karin, M. Inflammation, autophagy, and obesity: Common features in the pathogenesis of pancreatitis and pancreatic cancer. Gastroenterology 2013, 144, 1199-1209. [CrossRef] [PubMed]

56. Jensen, M.K.; Koh-Banerjee, P.; Franz, M.; Sampson, L.; Grønbaek, M.; Rimm, E.B. Whole grains, bran, and germ in relation to homocysteine and markers of glycemic control, lipids, and inflammation 1. Am. J. Clin. Nutr. 2006, 83, 275-283. [PubMed]

57. Lin, H.L.; An, Q.Z.; Wang, Q.Z.; Liu, C.X. Folate intake and pancreatic cancer risk: An overall and dose-response meta-analysis. Public Health 2013, 127, 607-613. [CrossRef] [PubMed]

58. Anderson, K.E.; Kadlubar, F.F.; Kulldorff, M.; Harnack, L.; Gross, M.; Lang, N.P.; Barber, C.; Rothman, N.; Sinha, R. Dietary intake of heterocyclic amines and benzo(a)pyrene: Associations with pancreatic cancer. Cancer Epidemiol. Biomark. Prev. 2005, 4, 2261-2265. [CrossRef] [PubMed]

59. McCord, J.M. Iron, free radicals, and oxidative injury. Semin. Hematol. 1998, 35, 5-12. [PubMed]

60. Sanchez, G.V.; Weinstein, S.J.; Stolzenberg-Solomon, R.Z. Is dietary fat, vitamin, D.; or folate associated with pancreatic cancer? Mol. Carcinog. 2012, 51, 119-127. [CrossRef] [PubMed]

61. Risch, H.A. Etiology of pancreatic cancer, with a hypothesis concerning the role of N-nitroso compounds and excess gastric acidity. J. Natl. Cancer Inst. 2003, 95, 948-960. [CrossRef] [PubMed]

62. Seitz, H.K.; Stickel, F. Molecular mechanisms of alcohol-mediated carcinogenesis. Nat. Rev. Cancer 2007, 7, 599-612. [CrossRef] [PubMed] 
63. Apte, M.V.; Pirola, R.C.; Wilson, J.S. Battle-scarred pancreas: Role of alcohol and pancreatic stellate cells in pancreatic fibrosis. J. Gastroenterol. Hepatol. 2006, 21, S97-S101. [CrossRef] [PubMed]

64. Irving, H.M.; Samokhvalov, A.V.; Rehm, J. Alcohol as a risk factor for pancreatitis. A systematic review and meta-analysis. JOP 2009, 10, 387-392. [PubMed]

65. Duell, E.J. Epidemiology and potential mechanisms of tobacco smoking and heavy alcohol consumption in pancreatic cancer. Mol. Carcinog. 2012, 51, 40-52. [CrossRef] [PubMed]

66. Lazarus, R.; Sparrow, D.; Weiss, S.T. Alcohol intake and insulin levels: The Normative Aging Study. Am. J. Epidemiol. 1997, 145, 909-916. [CrossRef] [PubMed]

67. Rosato, V.; Tavani, A.; Bosetti, C.; Pelucchi, C.; Talamini, R.; Polesel, J.; Serraino, D.; Negri, E.; La Vecchia, C. Metabolic syndrome and pancreatic cancer risk: A case-control study in Italy and meta-analysis. Metabolism 2011, 60, 1372-1378. [PubMed]

68. Esposito, K.; Chiodini, P.; Colao, A.; Lenzi, A.; Giugliano, D. Metabolic syndrome and risk of cancer: A systematic review and meta-analysis. Diabetes Care 2012, 35, 2402-2411. [CrossRef] [PubMed]

(C) 2017 by the authors; licensee MDPI, Basel, Switzerland. This article is an open access article distributed under the terms and conditions of the Creative Commons Attribution (CC-BY) license (http://creativecommons.org/licenses/by/4.0/). 